\title{
Microbial Spectra, Physiological Response and Bioremediation Potential of Phragmites australis for Agricultural Production
}

\author{
Chimdi Mang Kalu, Molemi Evelyn Rauwane and Khayalethu Ntushelo* \\ Department of Agriculture and Animal Health, University of South Africa, Science Campus, Florida, South Africa
}

OPEN ACCESS

Edited by:

Everlon Cid Rigobelo,

São Paulo State University, Brazil

Reviewed by:

Luciano Gebler,

Brazilian Agricultural Research Corporation (EMBRAPA), Brazil

Roberta Mendes dos Santos, São Paulo State University, Brazil

*Correspondence: Khayalethu Ntushelo ntushk@unisa.ac.za

Specialty section:

This article was submitted to

Crop Biology and Sustainability, a section of the journal

Frontiers in Sustainable Food Systems

Received: 16 April 2021

Accepted: 19 August 2021

Published: 14 September 2021

Citation:

Kalu CM, Rauwane ME and Ntushelo K (2021) Microbial Spectra,

Physiological Response and

Bioremediation Potential of

Phragmites australis for Agricultural

Production.

Front. Sustain. Food Syst. 5:696196.

doi: 10.3389/fsufs.2021.696196
Common reed (Phragmites australis) can invade and dominate in its natural habitat which is mainly wetlands. It can tolerate harsh environments as well as remediate polluted and environmental degraded sites such as mine dumps and other polluted wastelands. For this reason, this can be a very critical reed to reclaim wastelands for agricultural use to ensure sustainability. The present review manuscript examined the microbial spectra of $P$. australis as recorded in various recent studies, its physiological response when growing under stress as well as complementation between rhizosphere microbes and physiological responses which result in plant growth promotion in the process of phytoremediation. Microbes associated with P. australis include Proteobacteria, Bacteriodetes, and Firmicutes, Fusobacteria, Actinobacteria, and Planctomycetes families of bacteria among others. Some of these microbes and arbuscular mycorrhizal fungi have facilitated plant growth and phytoremediation by $P$. australis. This is worthwhile considering that there are vast areas of polluted and wasted land which require reclamation for agricultural use. Common reed with its associated rhizosphere microbes can be utilized in these land reclamation efforts. This present study suggests further work to identify microbes which when administered to $P$. australis can stimulate its growth in polluted environments and help in land reclamation efforts for agricultural use.

Keywords: bioremediation, microbial spectra, physiological response, Phragmites australis, agricultural production

\section{INTRODUCTION}

Common reed (Phragmites australis) is an invasive helophytic grass which has great impact on the ecosystem. It is tall, slender with a bare stem and plume-like inflorescence. Phragmites australis is found in brackish and freshwater wetlands, temperate and tropical regions of the world (Den et al., 1989; Brix, 1999; Meyerson et al., 2000). The ability of this reed to proliferate and survive in diverse environmental conditions and invade the environment could be traced to its high productivity (Kettenring et al., 2012; Douhovnikoff and Hazelton, 2014; Eller et al., 2014; Saltonstall et al., 2014). The common reed can competitively displace indigenous vegetation; hence, it is referred to as an invasive plant. In places where it has become a nuisance, control measures are devised to limit its spread and its encroachment in the natural arena. Methods to curb its spread include cutting and burning, flooding, the use of natural enemies, and application of herbicides. Some of the methods are effective but some show very little success (Reimer, 1976; Thompson and Shay, 1985; Monterio et al., 1999; Ailstock et al., 2001; Gusewell, 2003; Relyea, 2005; Avers et al., 2007). 
Despite the need to control its spread $P$. australis has been found useful as a bioremediator of polluted environments due to its ability to survive under stress (Windham et al., 2003; Weis and Weis, 2004; Duman et al., 2007; Bragato et al., 2009; Cerne et al., 2011). The ability of $P$. australis to remediate the environment results from its various genetic and physiological characteristics and these include having the ability to create a rhizosphere environment which encourages the habitation and proliferation of certain rhizosphere microbes. The common reed exudes enzymes and other cell contents which make its rhizosphere conducive for habitation by a myriad of mutually beneficial microbes. Nejla et al. (2014) observed a significant positive correlation between soil dehydrogenase activity (DHA) and pentachlorophenol (PCP) removal in polluted soils with the aid of microorganisms present in the reed's rhizosphere. This implied that microorganisms in the rhizosphere of $P$. australis and the enzyme activities promoted the biodegradation of PCP and the reclamation of the land. Work done by Cheema et al. (2009) and Yang et al. (2011) supported the findings of Nejla et al. (2014), whereby they observed both microbial and enzymatic activities as influenced by the root exudates promoted the remediation of the environment and freeing it of contaminants.

A plethora of the studies confirmed the findings that the rhizosphere of $P$. australis harbors diverse microorganisms that act as growth-promoting microbes which aid the growth of the reed and promote the remediation of the environment (Kadlec and Wallace, 2008; Jiang et al., 2013; Li et al., 2013; Zou et al., 2013; Bouali et al., 2014). This present review collated information on the microbial spectra associated with the rhizosphere of $P$. australis and the physiological response of the reed to environmental stress as well as the reed-microbes interaction that promotes the growth of the reed and enhance its bioremediation potential in the reclamation of land for agricultural use.

\section{DISTRIBUTION, IMPACT, AND USES OF PHRAGMITES AUSTRALIS}

The common reed originates from Europe. However, traces of a North American origin exist (Saltonstall, 2002). Research involving molecular markers showed that the species that were not a native pedigree of the reed were introduced in North America, and these species are behind the sporadic increase of the reed in North America (Chambers et al., 1999; Saltonstall, 2002). Catling and Mitrow (2012) pointed out that the abundance of the reed in North America is an attribute of the sporadic, but similar-looking European subspecies of the reed. Pollution, eutrophication, and shoreline development are notable factors contributing to the distribution and abundance of the reed in North America for the past 150 years (Marks et al., 1994; Chambers et al., 1999). Chambers et al. (1999) further reported that the distribution and abundance of the reed increased across the continent.

Very little is known about this reed on the African continent. However, some work has been done in southern Africa where $P$. australis is considered native based on pollen fossil records which point to presence in the southern African region since the Late Quaternary period (Scott, 1982). Due to intense mining in South Africa and the need to rehabilitate mine dumps and acid mine wetlands, this reed has been very important as a primary remediator of many of these polluted sites. This led to the prevalence of the common reed in aquatic and semi-aquatic areas especially in riverbeds and wet places (Gibbs et al., 1990; Van Oudtshoorn, 1999; Leistner, 2000) as well as in various heavy metal polluted areas adjacent to the mines. The common reed displaces indigenous vegetation through its competitive ability hence reducing the biodiversity of native plants (Catling and Mitrow, 2012). It forms thickets of vegetation because of high biomass formed by the reed leading to the blockage of light rays needed for the growth of the native fauna. Consequently, native plants less competitive than $P$. australis receive less sunlight, photosynthesize poorly, and are eventually crowded out and displaced.

Physiologically, the reed produces gallic acid which is broken down in the presence of ultraviolet light rays to form mesoxalic acid, a toxic chemical that hinders the growth of susceptible plants and seedlings native in the area (Thimmaraju et al., 2009). Controlling the growth of this common reed is a global concern and burning of the reed and its use as a forage for goats (Jolly, 2017) are believed to be the most effective methods for its control. The reed has some important uses despite its negative impact to the environment and biodiversity. The reed is used in weapon production like spears used for game hunting. It also provides shelter for birds and other kinds of animals. Some of its parts like the rootstocks are ground into flour or made into a thin liquid food of oatmeal and can be roasted in a moist state and eaten (Peterson, 2010). The reed is also known for its bioremediation role in most polluted environments because of its ability to strive well in harsh conditions and the microbe-plant interaction that is predominant with reeds and promote their growth as well as enhance their remediation potential.

\section{MICROBIAL CONSORTIA ASSOCIATED WITH PHRAGMITES AUSTRALIS IN ENVIRONMENTAL REMEDIATION}

Plants are inhabited by microbes either as endophytes or as exctophytes or as pathogens. As colonizers of plants, microbes form either mutually beneficial relationships with plants playing crucial roles in recycling of nutrients and breaking down of pollutants (Srivastava et al., 2017; Lyu et al., 2020). Plant parts which are most likely inhabited by ectophytes are those which have high nutrient levels such as secretion organs. The rhizosphere is one of the environment-plant interfaces most colonized by ectophytic microbes and provides environment laden with oxygen and nutrients for microbes' proliferation (Stottmeister et al., 2003). Microorganisms dominating the rhizosphere of macrophytes have been recorded to play important biological functions which include nutrient acquisition (Pii et al., 2015) that enhances growth and fitness, disease suppression (Mendes et al., 2011), and stress tolerance of the macrophytes (de Zelicourt et al., 
2013). These important plant-microbe interactions have led to expanded research into these associations and how they impact the remediation potentials of the macrophytes.

Remediation of polluted environments by plants is partly dependent on the interaction between plants and their associated microbes. Plant growth-promoting rhizobacteria in synergy with the associated plant have been proven to play a major role to clean-up of pollutants from polluted soils. However, several endophytes, mycorrhizae and algae contribute immensely to environmental remediation. Root zone microbes have been beneficial in constructed wetlands to remove soil contaminants. The interplay of root zone microbes in association with plants has been revealed in a plethora of studies which include the study by Zhang et al. (2021) which showed that adjusting plantbacteria interactions in the rhizosphere community of plants is an important aspect of phytoremediation. Similarly, Wang et al. (2020) found that the presence of denitrifying bacteria, in the root zone, guarantees high $\mathrm{NO}_{3}-\mathrm{N}$ removal efficiency from saturated soils. These established principles form the basis of constructing efficient wetlands for the removal of contaminants from soil.

Constructed wetlands have been adopted for the past decades in the remediation of contaminated environments because the method is cost-effective and devoid of any environmental damage (Kadlec and Wallace, 2008; Li et al., 2013; Zou et al., 2013; Bouali et al., 2014). Chandra et al. (2012) pointed out that $P$. australis has been employed in wetlands remediation of contaminated environment in both tropical and temperate part of the world. Ravit et al. (2003) stated that the plants' high biomass, root depth, ability to thrive well and breakdown pollutants, and ability to adapt easily are the bases upon which the reed and other species of plants used in bioremediation are selected. However, the effectiveness of the constructed wetlands in the treatment of polluted environment is dependent on the microbial consortia present in the rhizosphere of plant species selected for the bioremediation (Tian et al., 2014). Some of these microbes enhance plants' development (Jiang et al., 2013) and possibly promote the bioremediation process.

Shaw et al. (2006) views the rhizosphere as an exceptional zone around the root that is known for complex biological activities involving many microorganisms. Raaijmakers et al. (2009) pointed out that among the various microbes present in the rhizosphere, bacterial populations play a vital role in most activities in the rhizosphere because of their high level of host specificity. The various communities of bacteria present in the rhizosphere assist plants in the acquisition of inorganic nutrients, promote nitrogen uptake as well as protecting plants against attack by pathogenic fungi (Cocking, 2003; Berg et al., 2005; Uroz et al., 2007). Because of the importance of bacteria in natural ecosystems, it becomes necessary to unravel the bacterial diversity and possibly the bacteria-plant interactions in the habitats and how they aid in polluted land reclamation for crop production.

Microbial consortia of many wetland plants' roots have been investigated via culture-dependent and molecular methods (Jiang et al., 2013; Li et al., 2013; Abed et al., 2018). The era of highthroughput genomic technologies accelerated the discovery of root zones microbes as well as their biological activities. The uncovering of the microbial consortia and microbial metabolic activity was through the new fields of metagenomics and meta transcritomics. Notably studies include Kumar et al. (2018) which uncovered the rhizobacteria population composition of barley and alfafa in oil-contaminated soils. Another noteworthy study is that of Brereton et al. (2020) which cataloged the rhizosphere microbiome of Festuca arundinacea, Salix miyabeana and Medicago sativa in contaminated soil. In addition, Kalu et al. (2021) investigated the fungal and metabolome diversity of rhizosphere and endosphere of $P$. australis in an acid minepolluted environment. Furthermore, Mang and Ntushelo (2021) investigated the influence of acid mine water on the diversity and metabolite shift of microbial populations of the common reed. Obieze et al. (2020) investigated the functional attributes and response of bacterial communities to nature-based fertilization during hydrocarbon remediation. Bledsoe et al. (2020) observed increased bacterial diversity in bulk soils and plant rhizospheres in a long-term nutrient enriched oligotroph-dominated wetland. $\mathrm{Hu}$ et al. (2021) investigated the composition and co-occurrence patterns of $P$. australis rhizosphere bacterial community and observed the characterization of the rhizosphere by Arthrobacter, Pseudomonas, Trichococcus, and Ramlibacter that also played a crucial role in the regulation of plant fitness and nutrient cycling. Lyu et al. (2020) observed that bacterial phyla enriched in the rhizosphere of $P$. australis were found to be putative keystone taxa and might be involved in the regulation of bacterial interactions and plant growth. The investigation of the sediment microbiomes associated with the rhizosphere of emergent macrophytes in a shallow, subtropical lake by Huang et al. (2020) suggested that rhizosphere microbiome communities are influenced by the presence of macrophyte roots, with oxygenated rhizosphere and surface sediment communities being more diverse, and organized into more interconnected cooccurrence networks.

Metatranscriptomic studies which have accelerated our understanding of rhizosphere microbes in relation to phytoremediation include those by Yergeau et al. (2018) and Gonzalez et al. (2018) which both revealed the metatranscriptomics of the root zone in plants growing in contaminated soils with huge implications for phytoremediation. The exudates from the roots of plants are known to promote the growth and actions of rhizosphere associated microbes (Jiang et al., 2013; Zou et al., 2013). Most of the constructed wetlands are based on the principle of microbes-host plant interaction enhanced through the exudates from the plant. Abed et al. (2014) pointed out that there are very little wetlands built for bioremediation of oil polluted water. Few studies done fronted well-constructed wetlands as an effective bioremediation method for hydrocarbons contaminated water (Zou et al., 2013; Tian et al., 2014). One of the largest surface flows constructed wetland system in Oman, Arabian Gulf region, for oil-produced water remediation is predominated by $P$. australis (Abed et al., 2014). However, the knowledge of the microbial consortia of the reed's rhizosphere in oil-polluted wetlands is still minimal. Abed et al. (2018) reported bacterial communities in the rhizosphere of the reed from an oil-polluted wetland using molecular (Illumina MiSeq sequencing) and culture-based methods, and showed that 
the dominant phyla belonged to Proteobacteria, Bacteriodetes, and Firmicutes.

Integration of constructed wetland into the landscape could provide an efficient remediation of organic pollutants (Lorah and Voytek, 2004). Phragmites sp. and Typha angustifolia known as wetland plants have been shown in various studies to possess the potential of remediating chlorinated pollutants (Ma and Burken, 2002; Miglioranza et al., 2004; Zhang et al., 2005; Gomez-Hermosillo et al., 2006; Monferran et al., 2007; Ma and Havelka, 2009; Faure et al., 2012; San et al., 2013). Furthermore, some studies done have shown that most mineralization of recalcitrant organic contaminants occur at the rhizosphere (Kuiper et al., 2004; Krutz et al., 2005; Kidd et al., 2008; Gerhardt et al., 2009). A study of San et al. (2014) used pyrosequencing approaches to show that the rhizosphere of the reed in organochlorine contaminated soil were dominated by the phyla Proteobacteria. Furthermore, they identified Sphingomonas sp., Pseudomonas sp., Devosia sp. and Sphingobium sp. to be persistent in the organochlorine's environment indicating them as potential bioremediation microorganisms. Ding et al. (2021b) identified the following genera Rhodobacter, Catellibacterium, Hydrogenophaga, Geothrix and Aeromonas as colonizers of the rhizosphere of $P$. australis and these facilitate the removal $\mathrm{NH}_{4}^{+}-\mathrm{N}$ and chemical oxygen demand from the constructed wetland.

The significance of microbes-plant interaction has prompted many studies to be focussed on the interactions between microbes and $P$. australis. In wetlands colonized by the reed, the endophytic bacteria clustered into phyla Proteobacteria, Firmicutes, Bacteroidetes, Fusobacteria and small portion of unidentified bacteria have the potential to promote phytoremediation ( $\mathrm{Li}$ et al., 2010). However, Borsodi et al. (2007) observed less diverse periphyton bacterial communities that were clustered into phyla Proteobacteria, Firmicutes and Actinobacteria in the reed using culture-dependent methods. Vladàr et al. (2008) identified Desulfovibrio, Desulfotomaculum, and Desulfobulbus as the reed rhizosphere's sulfate-reducing bacteria. Work done by Zhang et al. (2013) on bacterial diversity of the rhizosphere of three ecotypes of the reed using the pyrosequencing approach showed the following phyla Proteobacteria, Actinobacteria, Bacteroidetes, Chloroflexi, Gemmatimonadetes and Planctomycetes to be the dominant bacterial cluster although differences in bacterial diversity existed in the different ecotypes.

A brief description of the roles of the bacterial communities colonizing the rhizosphere of $P$. australis provided an indication of their role in enhancing the growth of this reed, promoting their bioremediation ability necessary to reclaim polluted agricultural lands for expanded agricultural production. The genera Methylophilales, Nitrosomonadales, and Desulfuromonadales belonging to the phylum Proteobacteria have been reported to play a crucial role in nitrogen, sulfur, and global carbon recycling that enhances the growth of the reed and promote their phytoremediation ability (Ansola et al., 2014). Bacteroidetes has been reported to be actively involved in nitrogen fixation, a major component of the nitrogen cycle needed to enrich the soil and promote crop production in various species of halophytes (Alishahi et al., 2020). Cyanobacteria promote degradation of organic pollutants and enhance the process of the carbon cycle (Savage et al., 2010; Wang et al., 2016). Betaproteobacteria has varieties of ammonia oxidizing bacteria that enhance the removal of excess nitrogen that could constitute a major challenge to the growth of crops (Wang et al., 2013). Other denitrifying bacteria associated with the rhizosphere of $P$. australis include Catellibacterium (Kong et al., 2019), Hydrogenophaga (Xing et al., 2018), Aeromonas (Sun et al., 2019), and Geothrix (Zhang et al., 2010). Sediminibacterium was reported to play vital role in the biodegradation of vinyl chloride (Wilson et al., 2016). Acidovorax enhances the removal of heavy metals (Zhang et al., 2019). Geobacter promotes the removal of amino acids and organic acids in systems under suitable conditions ( $\mathrm{Lu}$ et al., 2015). Bacillus biodegrades various organic compounds necessary for dissolved organic carbon reduction (Guan et al., 2015). Nitrosospira ammonia oxidizing bacteria promote nitrogen cycling (Dong and Reddy, 2012). Flavobacterium promotes denitrification treatment nitrogenous contaminants (Pishgar et al., 2019). Thauera stimulate organic matter removal through enzyme secretion pathway that enhances chemical oxygen demand removal efficiency (Sanchez et al., 2018). The above alluded roles of these bacterial communities colonizing this rhizosphere of this reed contribute immensely to the growth of the reed while promoting the bioremediation potential as well as reclamation of contaminated agricultural land and enhancing agricultural production.

As previously mentioned in this review, the advancement in the sequencing technologies and computational analysis have unveiled knowledge on spectra of microorganisms which colonize the rhizosphere. Alegria et al. (2016) stated that the wetland plants microbiota could promote phytodepuration. Pietrangelo et al. (2018) showed composition and functional capability of bacteria microbiota of the rhizosphere of $P$. australis and T. latifolia using Illumina MiSeq sequencing techniques that the rhizosphere is dominated by Actinobacteria, Firmicutes, Proteobacteria, and Planctomycetes. However, the microbiota assemblage compositions and their potential contribution to phytodepuration needs further research. Table 1 provides a summary of the microbial spectra associated with $P$. austrialis in the remediation of polluted environments.

Aquatic macrophytes control their physiological activity to enhance their adaptation to changes in the environment. $P$. australis enhances its ability to survive under flooding conditions by increasing the rate of evapotranspiration to enhance its protection and uptake of nutrients (Zhao et al., 2012; Srivastava et al., 2014). Furthermore, these macrophytes, through plant residue decomposition, nutrients uptake, and root exudates, modify the physiochemical parameters of the soil to enable their proliferation and possibly the remediation of the environment (Luigimaria et al., 2014; Hallin et al., 2015; Packer et al., 2017). Hence, the next subsection of this review looked at the physiological response of $P$. australis to environmental stress. 
TABLE 1 | Summary of the microbial spectra associated with $P$. australis in the remediation of polluted environment.

\begin{tabular}{|c|c|c|c|c|}
\hline Remediation sites & Source of microorganism & Methods of identification & Phylum/Family of organisms & References \\
\hline Oil-polluted wetlands & Rhizosphere & $\begin{array}{l}\text { Molecular (illumina MiSeq } \\
\text { sequencing) and culture-based }\end{array}$ & $\begin{array}{l}\text { Proteobacteria, } \\
\text { Bacteriodetes, and } \\
\text { Firmicutes }\end{array}$ & Abed et al. (2018) \\
\hline $\begin{array}{l}\text { Organochlorines } \\
\text { contaminated sites }\end{array}$ & Rhizosphere & $\begin{array}{l}\text { Molecular (Pyrosequencing } \\
\text { approach) }\end{array}$ & Proteobacteria & San et al. (2014) \\
\hline Constructed wetland & Endophytes & $\begin{array}{l}\text { Culture-independent method } \\
\text { and }\end{array}$ & $\begin{array}{l}\text { Proteobacteria, } \\
\text { Firmicutes, } \\
\text { Bacteroidetes, } \\
\text { Fusobacteria }\end{array}$ & Li et al. (2010) \\
\hline Lake & Periphyton Samples & Culture-based method & $\begin{array}{l}\text { Proteobacteria, } \\
\text { Firmicutes and } \\
\text { Actinobacteria }\end{array}$ & Borsodi et al. (2007) \\
\hline Lake & Rhizosphere & $\begin{array}{l}\text { Culture-based and molecular } \\
\text { method }\end{array}$ & $\begin{array}{l}\text { Proteobacteria } \\
\text { Firmicutes }\end{array}$ & Vladàr et al. (2008) \\
\hline $\begin{array}{l}\text { Tailing dam of Mintails Mogale } \\
\text { Gold Mine and Sibanye Gold } \\
\text { Mine }\end{array}$ & Rhizosphere and endosphere & $\begin{array}{l}\text { MiSeq high-throughput } \\
\text { technology }\end{array}$ & $\begin{array}{l}\text { Ascomycota and } \\
\text { Basidiomycota }\end{array}$ & Kalu et al. (2021) \\
\hline Constructed wetland & Rhizosphere & $\begin{array}{l}\text { Quantitative polymerase chain } \\
\text { reaction (qPCR) }\end{array}$ & $\begin{array}{l}\text { Rhodobacter, } \\
\text { Catellibacterium, } \\
\text { Hydrogenophaga, } \\
\text { Geothrix and } \\
\text { Aeromonas }\end{array}$ & Ding et al. (2021b) \\
\hline
\end{tabular}

\section{PHYSIOLOGICAL RESPONSE OF PHRAGMITES AUSTRALIS IN STRESSED ENVIRONMENT}

Response of plants to environmental stress is dynamic and it involves physiological, metabolic, and molecular responses which all constitute plant fitness. Some plants only survive stress but have their growth and reproduction retarded. However, some survive and still manage to grow and proliferate in the presence of stress. The focus of this section is the physiological response of $P$. australis to stress in polluted environments. The authors demonstrate the unique physiological response which enables $P$. australis dominance in polluted environments.

Physiological response of plants and microorganisms in a stressed environment varies with the types and levels of stress. The physiological response involves the production of metabolites that promotes their survival or remediation potential. In view of the ability of $P$. australis to thrive well in stressed environments, a myriad of studies investigated the physiological dynamics of this reed when growing under 
stressed environments as a factor that contributes to their survival. Majken et al. (2005) showed that P. australis responds physiologically to water deficit stress through the production of the metabolite proline. Proline is believed to enhance the plant survival in the water deficit environment. In a regime of drought and flooding Wen et al. (2017) found that $P$. australis net photosynthetic rate, stomatal conductance, intercellular $\mathrm{CO}_{2}$, and transpiration rates decreased with prolonged drought stress and the delay in subsequent flooding after the drought. However, this reed is able to increase its physiological response even before it receives flooding under which it copes better. This shows a balance between water conversation and growth. This is probably a coping measure to conserve water to ensure water retention within the plant during water scarcity but on the other hand, maintain a foliage that allows the plant to undertake its various biological and ecological functions. In the saline-alkaline marsh in which the reed was growing, it accumulated more $\mathrm{Na}^{+}$in the shoots after long-term drought stress showing a self-regulatory mechanism of ion balance in different organs with increasing drought stress. Most recently, Ding and Sun (2021) found that various depths of flooding of $P$. australis triggered varying physiologic responses with leaf blades maintaining high enzyme activity and proline content while leaf sheaths maintained the greatest amount of soluble protein again demonstrating an orchestrated physiological response to flooding characterized by tissue specialization.

Similarly, in an earlier study Ding et al. (2021a), in a more targeted $P$. australis study about the role of tissue in partitioning various metals found that leaf sheaths had the highest potential to store metals of all the organs observed. The highest translocation factor for $\mathrm{Fe}$ was observed from the stems to the leaf sheaths and a higher bio-concentration factor for $\mathrm{Mn}$ was found in the leaf blades and leaf sheaths with $\mathrm{Cd}$ and $\mathrm{Zn}$ higher bio-concentration factors observed in the stems. This demonstrated tissue specialization in $P$. australis in stress resistance. Investigating the enrichment characteristics and biological response of $P$. australis to sulfamethoxazole and ofloxacin residues, Lv et al. (2020) found that sulfamethoxazole and ofloxacin accumulated in the plant in the rank root $>$ leaf $>$ stem and accumulation and transport of ofloxacin was higher than that of sulfamethoxazole. Besides these few studies, other studies have uncovered the physiologic responses of $P$. australis to stress and found results which have implications for the use of this reed as a phytoremediator. This includes the study of Wu et al. (2020) who investigated the responses of $P$. australis to $\mathrm{Cu}$ stress using a combined approach which employed morphology, physiology, and proteomics. Dayou et al. (2021) investigated trait-based adaptability of $P$. australis to the effects of soil water and salinity in the Yellow River Delta. The authors observed reduction in the average height and stem diameter with increase in leaf water content and thickness as well as salinity stress tolerant strategy in $P$. australis that enables the reed to dominate the river. Wahman et al. (2021) evaluated the changes in the metabolome profiles of $P$. australis when exposed to stress caused by drugs using a serial coupling of reversed-phase liquid chromatography and hydrophilic interaction liquid chromatography combined with accurate high-resolution time-of-flight mass spectrometer (TOFMS) and observed variation in the metabolites shift in respect to different drugs. Strikingly, an increase in the production of quercetin was observed by the authors in the plant after diclofenac incubation.

Pflugmacher et al. (2001) observed the production of glutathione conjugate and cysteine conjugate in all cormus part of $P$. australis in the complete metabolism of cyanobacterial toxin microcystin and enzymes such as glutathione S-transferases (sGST) that enhances the complete breakdown of the toxins. Sauvêtre et al. (2018) observed the production of metabolites involving GSH conjugation and 2,3-dihydroxylation, as well as acridine related compounds in Armoracia rusticana (hair root culture) treated with endophytic bacteria from $P$. australis in response to carbamazepine (CBZ) exposure. Carbamazepine is known as a recalcitrant pharmaceutical pollutant in the aquatic environment. In their work, higher removal rate of $\mathrm{CBZ}$ and metabolite production were observed when the endophytes were introduced. This implied that the endophytes could enhance the development of the plant and promote the breakdown of CBZ.

In addition, Luisa et al. (2004) reported increased production of phytochelatins, and antioxidant enzymes such as glutathione reductase, glutathione-S-transferase, catalase, ascorbate peroxidase, dehydroascorbate reductase, guaiacol peroxidase in $P$. australis when exposed to increased concentration of Cd. Sulaiman and Alfadul (2013) also observed increased production of metabolites such as malondialdehyde, aspartate, glutamate, serine, histidine, glycine, threonine, cysteine, valine, methionine, phenylalanine, isoleucine, leucine, lysine, proline, and the activities of antioxidant enzymes such as superoxide dismutase, catalase, ascorbate peroxidase, glutathione peroxidase and peroxidase in response to the increase concentration $\mathrm{Cd}$, $\mathrm{Zn}, \mathrm{Cu}$, and $\mathrm{Pb}$. P. australis' increase production of metabolites and antioxidant enzymes are stress response of the plant to the increase concentrations of heavy metals which enhance its survival and sequestration of heavy metals by the plant. Table 2 provides a summary of metabolites produced as well as synthesized enzymes by $P$. australis in a stressed environment. The interaction between $P$. australis and associated rhizospheric microbes and endophytes is believed to initiate physiological response leading to the production of diverse metabolites either by the reed or associated microbes that have the tendency to promote growth and bioremediation potential of the reed.

\section{INTERACTION OF THE STRESS INDUCED PHYSIOLOGICAL RESPONSES AND RHIZOSPHERE MICROBES OF PHRAGMITES AUSTRALIS AS FACILITATOR OF GROWTH AND BIOREMEDIATION POTENTIAL OF THE REED}

The plant environment from the roots to the apex is a continuum of physiological and metabolic activity under various influences either internal such as genetic or external such 
TABLE 2 | Summary of the metabolites produced, and enzymes synthesized by P. australis in response to stress.

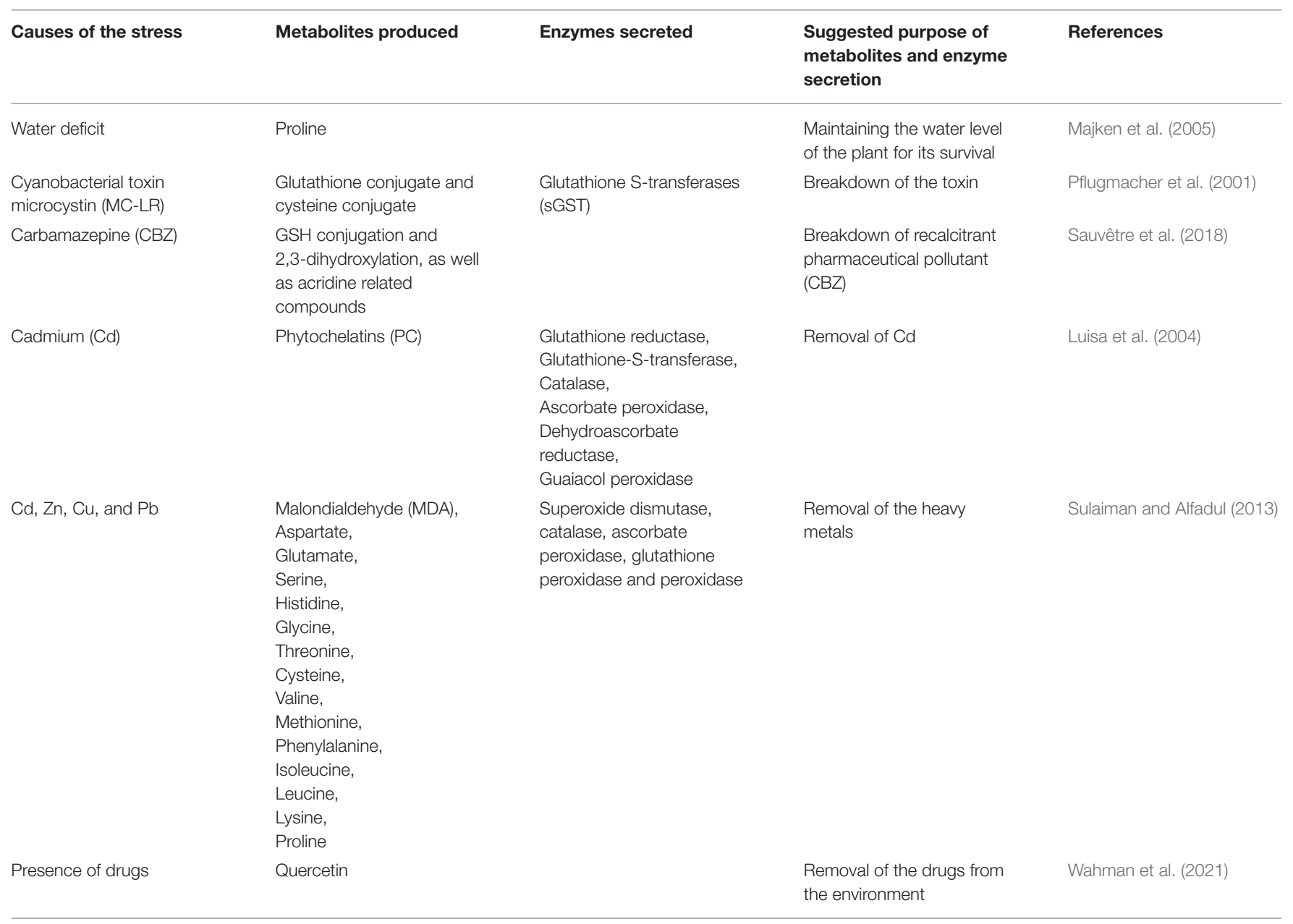

as the environment characterized by the climate, ecological interactions, and the condition of the soil. Given this proven fact, it is logical that rhizosphere microbes influence the response of the plant to environmental stress. This has been proven in many studies, but we limit our focus on the effect of rhizosphere microbes on the physiological responses of $P$. australis to stress, in particular stress related to soil pollution. We also look at the use of rhizosphere microbes to improve the bioremediation efforts of $P$. australis. These include the use of rhizosphere microbes to first degrade complex chains of pollutant compounds into their smaller subunits for easier adsorption by the reed.

For the reclamation of polluted land needed for the growth of crops and sustainability of agricultural production, there is a serious need to unravel various microbial communities in association with stress resistant plants which include macrophytes like $P$. australis and the physiological mechanisms adopted by the plants that could aid in the remediation of the contaminated land. Toyama et al. (2009) evaluated the biodegradation of bisphenol A (BPA) and bisphenol F (BPF) in rhizosphere sediment of $P$. australis. Bisphenols are endocrine disrupting chemicals with the potentials to cause adverse effect on human health and other animals when released on land and absorbed by crops (Chen et al., 2002; Crain et al., 2007). Consequent upon the adverse effect of bisphenols, there existed the need to remediate the environment contaminated with these chemicals. The authors observed a high rate of BPA and BPF removal and the presence of A BPA-degrading bacterium, Novosphingobium sp. strain TYA-1, and a BPFdegrading bacterium, Sphingobium yanoikuyae strain TYF-1. The results suggested that the interactions of $P$. australis and these bacteria can speed up the rate of removal of bisphenols from the sediment (Toyama et al., 2009).

Nejla et al. (2014) examined the phytoremediation potential of $P$. australis grown in pentachlorophenol and cadmium co-contaminated soils. They observed significant positive correlation between soil dehydrogenase activity (DHA) and pentachlorophenol (PCP) removal in planted soil implying that $P$. australis enhanced the biodegradation of PCP through the activities of enzymes and the microorganisms in the rhizosphere of the plant. The degradation of cyanobacteria toxin microcystin by $P$. australis (Pflugmacher et al., 2001) provided a good indication of the application of the reed in the bioremediation of polluted agricultural land and the reclamation of the land for agricultural practices. Physiology and rhizosphere microbiology 
TABLE 3 | Remediation ability of $P$. australis in diverse polluted environment.

\begin{tabular}{|c|c|c|}
\hline Nature of the environment & Bioremediation potential & References \\
\hline Fe contaminated & $100 \%$ bioaccumulation of Fe & Batty (2003) \\
\hline $\mathrm{Cu}, \mathrm{Cd}, \mathrm{Ni}, \mathrm{Pb}$, and $\mathrm{Zn}$ contaminated aqueous solution & Adsorption of $\mathrm{Cu}, \mathrm{Cd}, \mathrm{Ni}, \mathrm{Pb}$, and $\mathrm{Zn}$ & Southichak et al. (2006) \\
\hline As and $\mathrm{Sb}$ contaminated & Removal of As and $\mathrm{Sb}$ & Ghassemzadeh et al. (2008) \\
\hline Cu contaminated & High Cu tolerance & Ali et al. (2002) \\
\hline Zn and Mn contaminated & High root accumulation of $\mathrm{Zn}$ and $\mathrm{Mn}$ & Peltier et al. (2003) \\
\hline $\mathrm{Cu}, \mathrm{Cd}, \mathrm{Cr}, \mathrm{Ni}, \mathrm{Fe}, \mathrm{Pb}$ and $\mathrm{Zn}$ contaminated & Removal of $\mathrm{Cu}, \mathrm{Cd}, \mathrm{Cr}, \mathrm{Ni}, \mathrm{Fe}, \mathrm{Pb}$ and $\mathrm{Zn}$ & Menka and Tripathi (2015) \\
\hline $\mathrm{Cd}, \mathrm{Cr}, \mathrm{Hg}, \mathrm{Mn}, \mathrm{Ni}, \mathrm{Pb}$, and $\mathrm{Zn}$ contaminated & $\begin{array}{l}\mathrm{Cd}, \mathrm{Cr}, \mathrm{Hg}, \mathrm{Mn}, \mathrm{Ni}, \mathrm{Pb} \text {, and } \mathrm{Zn} \text { accumulation in the order } \\
\text { root }>\text { rhizome> leaf }>\text { stem }\end{array}$ & $\begin{array}{l}\text { Bonanno and Lo Giudice } \\
\text { (2010) }\end{array}$ \\
\hline As and trace metal contaminated & Phytostabilization of As and trace metals & Paola et al. (2018) \\
\hline $\mathrm{Cd}, \mathrm{Cu}, \mathrm{Pb}$, and $\mathrm{Zn}$ contaminated sediments & Bioaccumulation of $\mathrm{Cd}, \mathrm{Cu}, \mathrm{Pb}$, and $\mathrm{Zn}$ & Fawazy et al. (2012) \\
\hline $\begin{array}{l}\text { Trace elements (Ag, Al, As, B, Ba, Be, Co, Fe, Mo, Pd, } \\
\text { Pt, Rh, Sb, Se, Sr, Tl, and V) contaminated }\end{array}$ & $\begin{array}{l}\text { Removal of } \mathrm{Ag}, \mathrm{Al}, \mathrm{As}, \mathrm{B}, \mathrm{Ba}, \mathrm{Be}, \mathrm{Co}, \mathrm{Fe}, \mathrm{Mo}, \mathrm{Pd}, \mathrm{Pt} \text {, } \\
\mathrm{Rh}, \mathrm{Sb}, \mathrm{Se}, \mathrm{Sr}, \mathrm{Tl} \text {, and } \mathrm{V} \text { in the order } \\
\text { root }>\text { rhizome }>\text { leaf }>\text { stem }\end{array}$ & Bonanno (2011) \\
\hline Co, Cr, Cu, Fe, Cd, Ni, Mn, and Zn contaminated & $\begin{array}{l}\text { High bioaccumulation of } \mathrm{Co}, \mathrm{Cr}, \mathrm{Cu}, \mathrm{Fe}, \mathrm{Ni}, \mathrm{Mn} \text {, and } \mathrm{Zn} \\
\text { in the roots and } \mathrm{Cd} \text {, and } \mathrm{Pb} \text { in the leaves }\end{array}$ & Rzymski et al. (2014) \\
\hline $\begin{array}{l}\text { Heavy metal (Co, Ni, Mo, Cd, Pb, Cr, Cu, Fe, Mn, Zn and } \\
\text { Hg) and trace metal (As, Se, Ba) contaminated estuarine } \\
\text { sediments }\end{array}$ & $\begin{array}{l}\text { Decrease the metals in the order } \mathrm{Fe}>\mathrm{Mn}>\mathrm{Zn}>\mathrm{Pb}> \\
\mathrm{Ba}>\mathrm{Cr}>\mathrm{As}>\mathrm{Cu}>\mathrm{Ni}>\mathrm{Co}>\mathrm{Mo}>\mathrm{Cd}>\mathrm{Se}>\mathrm{Hg}\end{array}$ & $\begin{array}{l}\text { Cicero-Fernández et al. } \\
\text { (2017) }\end{array}$ \\
\hline Bisphenol A (BPA) and bisphenol F (BPF) contaminated & $\begin{array}{l}\text { High rate of BPA and BPF removal in the presence of A } \\
\text { BPA-degrading bacterium, Novosphingobium sp. strain } \\
\text { TYA-1, and a BPF-degrading bacterium, Sphingobium } \\
\text { yanoikuyae strain TYF-1) in the rhizosphere sediment of } \\
\text { P. australis }\end{array}$ & Toyama et al. (2009) \\
\hline pentachlorophenol and cadmium co-contaminated soils & $\begin{array}{l}\text { Enhancement of the biodegradation of PCP through the } \\
\text { activities of soil dehydrogenase }(\mathrm{DHA}) \text { and the } \\
\text { microorganisms in the rhizosphere of the plant }\end{array}$ & Nejla et al. (2014) \\
\hline Butachlor contaminated & Degradation of butachlor & Yang et al. (2011) \\
\hline Urban runoff treatment & $\begin{array}{l}\text { Reduction of biological oxygen demand (BOD), and } \\
\text { remove large amount of nitrogen }\end{array}$ & $\begin{array}{l}\text { Byoung-Hwa and Miklas } \\
(2007)\end{array}$ \\
\hline Cyanobacterial toxin microcystin (MC-LR) contaminated & $\begin{array}{l}\text { Complete remediation of cyanobacterial toxin } \\
\text { microcystin (MC-LR) }\end{array}$ & Pflugmacher et al. (2001) \\
\hline $\mathrm{Ni}$ and $\mathrm{Pb}$ contamintated Lake Burullus, Egypt & Phytoextraction of $\mathrm{Ni}$ and $\mathrm{Pb}$ & Eid et al. (2021) \\
\hline
\end{tabular}

were also completed in the work of Fahid et al. (2020) who found that $P$. australis vegetated with three bacterial strains belonging to Acinetobacter and Bacillus had an improved capacity of hydrocarbon extraction from diesel contaminated water. Likewise, $P$. australis grew more rapidly in the presence of the bacteria which were also hydrocarbon degrading strains. This was more of a complementation exercise as the ability of the reed to adsorb hydrocarbons was probably because the long chain hydrocarbons had first been degraded by the bacteria to make them easier for adsorption by the reed. Plant growth promotion by rhizosphere microbes of the $P$. australis has been proven in several studies, and logically growth promotion can be seen to aid phytoremediation in places where this reed grows as a remediator of a polluted site. Riva et al. (2019) found that cultivable microbes isolated from the rhizosphere and the interior of $P$. australis in a constructed wetland in Morocco improved growth of Juncus acutus. Some of the strains improve the growth of $J$. acutus and its ability to remove azo-dyes. This indicates that the rhizosphere of $P$. australis is an enrichment niche for microbes which can be effectively used in phytoremediation even using a different plant species. Similarly,
Saleem et al. (2019) investigated the feasibility of $P$. australis in combination with Acinetobacter, Bacillus, and Pseudomonas in phenol degradation. The authors observed the colonization of the reed's rhizosphere by the microbes which aid in their growth and phenol degradation.

You et al. (2021) investigated the effect of arbuscular mycorrhizal fungi on the growth and toxic element uptake by $P$. australis under $\mathrm{Zn} / \mathrm{Cd}$ stress. The authors observed that the reduction of $\mathrm{Zn}$ and $\mathrm{Cd}$ toxicity in the reed as impacted by the actions of arbuscular mycorrhizal fungi via the increase of the reed biomass and regulatory patterns under different $\mathrm{Zn} / \mathrm{Cd}$ concentrations. Wu et al. (2020) found that inoculation of $P$. australis with arbuscular mychorrhizal fungi can relive this plant of photosynthesis inhibition caused by $\mathrm{Cu}$ stress as a result, promote the growth of the reed. This study proved the existence of a symbiotic relationship between the fungi and the plant, and this can be manipulated in several bioremediation efforts. Table 3 provided a summary of the remediation potentials of $P$. australis. The ability of $P$. australis to bioaccumulate heavy metals could be an attribute of the plant's growing periods and physiology (Windham et al., 2001). Furthermore, the 
bioremediation potential of $P$. australis could be attributed to the interaction between the reed and the associated microbes which is culminated with a lot of physiological response involving the production of metabolites and various enzymatic activities that can enhance the growth of the reed. The association between $P$. australis and its rhizosphere microbes has implications for phytoremediation of wastelands that can be reclaimed for agricultural use.

Proteobacteria, Bacteriodetes, and Firmicutes, Fusobacteria, Actinobacteria, and Planctomycetes are the major families of bacteria dominating the rhizosphere of $P$. australis. Some species belonging to this families as well as some arbuscular mycorrhizal fungi have been found to play major roles in the biological activities that promotes the growth of the reed and the reed's remediation potential. However, further research is required to unveil other species of bacteria and

\section{REFERENCES}

Abed, R. M. M., Al-Kharusi, S., Gkorezis, P., Prigent, S., and Headley, T. (2018). Bacterial communities in the rhizosphere of Phragmites australis from an oil-polluted wetland. Arch. Agron. Soil Sci. 64, 360-370. doi: 10.1080/03650340.2017.1352087

Abed, R. M. M., Al-Kharusi, S., Prigent, S., and Headley, T. (2014). Diversity, distribution and hydrocarbon biodegradation capabilities of microbial communities in oil-contaminated cyanobacterial mats from a constructed wetland. PLos ONE 9: e114570. doi: 10.1371/journal.pone.0114570

Ailstock, S. M., Norman, M. C., and Bushmann, P. J. (2001). Common reed Phragmites australis: control and effects upon biodiversity in freshwater nontidal wetlands. Restor. Ecol. 9, 49-59. doi: 10.1046/j.1526-100x.2001.009001049.x

Alegria, T. R., Giles, C., Paterson, E., Robertson-Albertyn, S., Cesco, S., Mimmo, T., et al. (2016). Plant-microbiota interactions as a driver of the mineral turnover in the rhizosphere. Adv. Appl. Microbiol. 95, 1-67. doi: 10.1016/bs.aambs.2016.03.001

Ali, N. A., Bernal, M. P., and Ater, M. (2002). Tolerance and bioaccumulation of copper in Phragmites australis and Zea mays. Plant Soil 239, 103-111. doi: 10.1023/A:1014995321560

Alishahi, F., Alikhani, H. A., Khoshkholgh-Sima, N. A., and Etesami, H. (2020). Mining the roots of various species of the halophyte Suaeda for halotolerant nitrogen-fixing endophytic bacteria with the potential for promoting plant growth. Int. Microbiol. 23, 415-427. doi: 10.1007/s10123-019-00115-y

Ansola, G., Arroyo, P., and Miera, L. E. S. (2014). Characterisation of the soil bacterial community structure and composition of natural and constructed wetlands. Sci. Total Environ. 473, 63-71. doi: 10.1016/j.scitotenv.2013.11.125

Avers, B., Fahlsing, R., Kafcas, E., Schafer, J., Collin, T., Esman, L., et al. (2007). A guide to the Control and Management of Invasive PHRAGMITES. Michigan Department of Environmental Quality, Lansing. Available online at: https:// www.invasive.org/publications/PhragBook

Batty, L. C. (2003). Wetland plants more than just a pretty face? Land Contamin. Reclam. 112, 173-180. doi: 10.2462/09670513.812

Berg, G., Krechel, A., Ditz, M., Sikora, R. A., Ulrich, A., and Hallmann, J. (2005). Endophytic and ectophytic potato associated bacterial communities differ in structure and antagonistic function against plant pathogenic fungi. FEMS Microbiol. Ecol. 51, 215-229. doi: 10.1016/j.femsec.2004.08.006

Bledsoe, R. B., Goodwillie, C., and Peralta, A. L. (2020). Long-term nutrient enrichment of an oligotroph-dominated wetland increases bacterial diversity in bulk soils and plant rhizospheres. mSphere 5:e00035-e00020. doi: $10.1128 / \mathrm{mSphere.00035-20}$

Bonanno, G. (2011). Trace element accumulation and distribution in the organs of Phragmites australis (common reed) and biomonitoring applications. Ecotoxicol. Environ. Saf. 74, 1057-1064. doi: 10.1016/j.ecoenv.2011.01.018 other microbes that can promote the growth of $P$. australis in polluted environment and enhance the phytoremediation process necessary for the reclamation of agricultural land for sustainable agricultural production.

\section{AUTHOR CONTRIBUTIONS}

$\mathrm{CK}, \mathrm{MR}$, and $\mathrm{KN}$ drafted the manuscript. $\mathrm{KN}$ also provided oversight of the writing process. All authors have read and approved the manuscript.

\section{ACKNOWLEDGMENTS}

The authors wish to thank the Agricultural Research CouncilUniversity of South Africa Climate Change Collaboration Center for their financial support.

Bonanno, G., and Lo Giudice, R. (2010). Heavy metal bioaccumulation by the organs of Phragmites australis (common reed) and their potential use as contamination indicators. Ecol. Indic. 10, 639-645. doi: 10.1016/j.ecolind.2009.11.002

Borsodi, A. K., Rusznyak, A., Molnar, P., Vladar, P., Reskone, M. N., Toth, E. M., et al. (2007). Metabolic activity and phylogenetic diversity of reed (Phragmites australis) periphyton bacterial communities in a Hungarian shallow soda lake. Microb. Ecol. 53, 612-620. doi: 10.1007/s00248-006-9133-x

Bouali, M., Feki, M., and Bakhrouf, A. (2014). Comparative study of two constructed wetlands for wastewater treatment. J. Chem. Biol. Phys. Sci. 4, 1680-1691. doi: 10.10691.jcbsc.org/admin/get_fileenv.php?id=139

Bragato, C., Schiavon, M., Polese, R., Ertani, A., Pittarello, M., and Malagoli, M. (2009). Seasonal variations of $\mathrm{Cu}, \mathrm{Zn}, \mathrm{Ni}$ and $\mathrm{Cr}$ concentration in Phragmites australis (Cav.) Trin ex steudel in a constructed wetland of North Italy. Desalination 246, 35-44. doi: 10.1016/j.desal.2008.02.036

Brereton, N. J. B., Gonzalez, E., Desjardins, D., and Labrecque, M.,Pitre, F.E. (2020). Co-cropping with three phytoremediation crops influences rhizosphere microbiome community in contaminated soil. Sci. Total Environ. 711:135067. doi: 10.1016/j.scitotenv.2019.135067

Brix, H. (1999). Genetic diversity, ecophysiology, and growth dynamics of reed (Phragmites australis). Aquat. Bot. 64, 179-184. doi: 10.1016/S0304-3770(99)00050-9

Byoung-Hwa, L., and Miklas, S. (2007). What is the role of Phragmites australis in experimental constructed wetland filters treating urban runoff? Ecol. Eng. 29, 87-95. doi: 10.1016/j.ecoleng.2006.08.001

Catling, P. M. and Mitrow, G., (2012). Major invasive alien plants of natural habitats in Canada: Common buckthorn, European buckthorn. Can. Bot. Assoc. Bull. 45, 110-117.

Cerne, M., Smodiš, B., and Štrok, M. (2011). Uptake of radionuclides by a common reed (Phragmites australis (Cav.) Trin. ex Steud.) grown in the vicinity of the former uranium mine at Žirovski vrh. Nucl. Eng. Des. 241, 1282-1286. doi: 10.1016/j.nucengdes.2010.04.003

Chambers, R. M., Meyerson, L. A., and Saltonstall, K. (1999). Expansion of Phragmites australis into tidal wetlands of North America. Aquat. Bot. 64, 261-273. doi: 10.1016/S0304-3770(99)00055-8

Chandra, R., Bharagava, R. N., Kapley, A., and Purohit, H. J. (2012). Characterization of Phragmites cummunis rhizosphere bacterial communities and metabolic products during the two-stage sequential treatment of post methanated distillery effluent by bacteria and wetland plants. Bioresour. Technol. 103, 78-86. doi: 10.1016/j.biortech.2011. 09.132

Cheema, S. A., Khan, M. I., Tang, X., Zhang, C., Shen, C., Malik, Z., et al. (2009). Enhancement of phenanthrene and pyrene degradation in rhizosphere of tall fescue (Festuca arundinacea). J. Hazard. Mater. 166, 1226-1231. doi: 10.1016/j.jhazmat.2008.12.027 
Chen, M. Y., Ike, M., and Fujita, M. (2002). Acute toxicity, mutagenicity, and estrogenicity of bisphenol-A and other bisphenols. Environ. Toxicol. 17, 80-86. doi: 10.1002/tox.10035

Cicero-Fernández, D., Manuel, P., Jose, A. E., and Blanca, A. (2017). Longterm (two annual cycles) phytoremediation of heavy metal-contaminated estuarine sediments by Phragmites australis. New Biotechnol. 38, 56-64. doi: 10.1016/j.nbt.2016.07.011

Cocking, E. C. (2003). Endophytic colonization of plant roots by nitrogen fixing bacteria. Plant Soil 252, 169-175. doi: 10.1023/A:1024106605806

Crain, D. A., Eriksen, M., Iguchi, T., Jobling, S., Laufer, H., LeBlanc, G. A., et al. (2007). An ecological assessment of bisphenol-A: evidence from comparative biology. Reprod. Toxicol. 24, 225-239. doi: 10.1016/j.reprotox.2007.05.008

Dayou, Z., Yuehan, N., Xiaona, Y.u., et al. (2021). Trait-based Adaptability of Phragmites Australis to the Effects of Soil Water and Salinity in the Yellow River Delta. Authorea.

de Zelicourt, A., Al-Yousif, M., and Hirt, H. (2013). Rhizosphere microbes as essential partners for plant stress tolerance. Mol. Plant 6, 242-245. doi: $10.1093 / \mathrm{mp} / \mathrm{sst} 028$

Den, H. C., Kvet, J., and Sukopp, H. (1989). Reed: a common species in decline. Aquat. Bot. 35, 1-4. doi: 10.1016/0304-3770(89)90062-4

Ding, J., Yingchao, J., Congcong, Z., Wenbin, B., Xiaoqing, X., Ruiyuan, L., et al. (2021b). Microbial abundance and community in constructed wetlands planted with Phragmites australis and Typha orientalis in winter. Int. J. Phytorem. 18, 399-405. doi: 10.1080/15226514.2021.1907737

Ding, Z., Fang, Q., Daraz, U., et al. (2021a). Physiological responses and metal distributions of different organs of Phragmites australis shoots under acid mine drainage stress. Environ. Sci. Pollut. Res. 28, 3375-3385. doi: 10.1007/s11356-020-10700-8

Ding, Z., and Sun, Q. (2021). Effects of flooding depth on metal (loid) absorption and physiological characteristics of Phragmites australis in acid mine drainage phytoremediation. Environ. Technol. Inn. 101512. doi: $10.1016 /$ j.eti.2021.101512

Dong, X., and Reddy, G. B. (2012). Ammonia-oxidizing bacterial community and nitrification rates in constructed wetlands treating swine wastewater. Ecol. Eng. 40, 189-197. doi: 10.1016/j.ecoleng.2011.12.022

Douhovnikoff, V., and Hazelton, E. L. (2014). Clonal growth: Invasion or stability? a comparative study of clonal architecture and diversity in native and introduced lineages of Phragmites australis (Poaceae). Am. J .Bot. 10, 1577-1584. doi: 10.3732/ajb.1400177

Duman, F., Cicek, M., and Sezen, G. (2007). Seasonal changes of metal accumulation and distribution in common club rush (Schoenoplectus lacustris) and common reed (Phragmites australis). Ecotoxicology 16, 457-463. doi: 10.1007/s10646-007-0150-4

Eid, E. M., Kamal, H. S., Yassin, M., Al-S, Soliman, A. H., Tarek, M. G., ·, Hamdi, A., et al. (2021). Temporal Potential of Phragmites australis as a Phytoremediator to Remove $\mathrm{Ni}$ and $\mathrm{Pb}$ from Water and Sediment in Lake Burullus, Egypt. Bull. Environ. Contam. Toxicol. 106, 516-527. doi: 10.1007/s00128-021-03120-y

Eller, F., Lambertini, C., Nguyen, L. X., and Brix, H. (2014). Increased invasive potential of non-native Phragmites australis: elevated $\mathrm{CO}_{2}$ and temperature alleviate salinity effects on photosynthesis and growth. Glob. Change Biol. 20, 531-543. doi: 10.1111/gcb.12346

Fahid, M., Arslan, M., Shabir, G., Younus, S., Yasmeen, T., Rizwan, M., et al. (2020). Phragmites australis in combination with hydrocarbons degrading bacteria is a suitable option for remediation of diesel-contaminated water in floating wetlands. Chemosphere 240:124890. doi: 10.1016/j.chemosphere.2019.124890

Faure, M., San, M. A., Ravanel, P., and Raveton, M. (2012). Concentration responses to organochlorines in Phragmites australis. Environ. Pollut. 164, 188-194. doi: 10.1016/j.envpol.2012.01.040

Fawazy, M. A., Badr, N. E. S., and Abo-El-Kassem, A. (2012). Heavy metal biomonitoring and phytoremediation potentialities of aquatic macrophytes in River Nile. Environ. Monit. Assess. 184, 1753-1771. doi: 10.1007/s10661-011-2076-9

Gerhardt, K. E., Huang, X. D., Glick, B. R., and Greenberg, B. M. (2009). Phytoremediation and rhizoremediation of organic soil contaminants: potential and challenges. Plant Sci. 176, 20-30. doi: 10.1016/j.plantsci.2008.09.014

Ghassemzadeh, F., Yousefzadeh, H., and Arbab-Zavar, M. H. (2008). Removing arsenic and antimony by Phragmites australis: rhizofiltration technology. J. Appl. Sci. 8, 1668-1675 doi: 10.3923/jas.2008.166 8.1675

Gibbs, G. E., Watson, L., Koekemoer, M., Smook, L., Barker, N. P., Anderson, H. M., et al. (1990). "Grasses of Southern Africa," in Memoirs of the Botanical Survey of South Africa No. 58.

Gomez-Hermosillo, C., Pardue, J. H., and Reible, D. D. (2006). Wetland plant uptake of desorption-resistant organic compounds from sediments. Environ. Sci. Technol. 40, 3229-3236. doi: 10.1021/es0513411

Gonzalez, E., Pitre, F. E., Pag,é, A. P., Marleau, J., Nissim, W. G., St-Arnaud, M., et al. (2018). Trees, fungi, and bacteria: tripartite metatranscriptomics of a root microbiome responding to soil contamination. Microbiome 6, 1-30. doi: 10.1186/s40168-018-0432-5

Guan, W., Yin, M., He, T., and Xie, S. (2015). Influence of substrate type on microbial community structure in vertical-flow constructed wetland treating polluted river water. Environ. Sci. Pollut. Res. 22, 16202-16209. doi: 10.1007/s11356-015-5160-9

Gusewell, S. (2003). Management of Phragmites australis in Swiss fen meadows by mowing in early summer. Wetl. Ecol. Manag. 11, 433-445. doi: 10.1023/B:WETL.0000007197.85070.58

Hallin, S., Hellman, M., Choudhury, M. I., and Ecke, F. (2015). Relative importance of plant uptake and plant associated denitrification for removal of nitrogen from mine drainage insub-arctic wetlands. Water Res. 85, 377-383. doi: 10.1016/j.watres.2015.08.060

Hu, S., He, R., Wang, W., Dayong, Z., Jin, Z., Rui, H., et al. (2021). Composition and co-occurrence patterns of Phragmites australis rhizosphere bacterial community. Aquatic Ecol. 4:9855. doi: 10.1007/s10452-021-0 9855-4

Huang, R., Zeng, J., Zhao, D. Y., Cook, K. V., Hambright, K. D., and Yu, Z. B. (2020). Sediment microbiomes associated with the rhizosphere of emergent macrophytes in a shallow, subtropical lake. Limnol. Oceanogr. 65, S38-S48 doi: 10.1002/lno.11325

Jiang, X. T., Peng, X., Deng, G. H., Sheng, H. F., Wang, Y., Zhou, H. W., et al. (2013). Illumina sequencing of $16 \mathrm{~S}$ rRNA Tag revealed spatial variations of bacterial communities in a Mangrove wetland. Environ. Microbiol. 66, 96-104. doi: 10.1007/s00248-013-0238-8

Jolly, J. (2017). The Goats Fighting America's Plant Invasion. Available online at: https://www.bbc.com/news/magazine-30583512

Kadlec, R. H., and Wallace, S. (2008). Treatment Wetlands. Boca Raton (FL). Boca, Raton: CRC Press. Available online at: http://colinmayfield.com/waterhealth/ course3/Resources/treatment-wetlands---kadlec-and-wallace---part-iv

Kalu, C. M., Henry, J. O. O., Ramganesh, S., Memory, T., and Ntushelo, K. (2021). Fungal and metabolome diversity of the rhizosphere and endosphere of Phragmites australis in an AMD-Polluted Environment. Heliyon 7:e06399. doi: 10.1016/j.heliyon.2021.e06399

Kettenring, K. M., de Blois, S., and Hauber, D. P. (2012). Moving from a regional to a continental perspective of Phragmites australis invasion in North America. AoB Plants 2012:pls040. doi: 10.1093/aobpla/pls040

Kidd, P. S., Prieto-Fernandez, A., Monterroso, C., and Acea, M. J. (2008). Rhizosphere microbial community and hexachlorocyclohexane degradative potential in contrasting plant species. Plant Soil 302, 233-247. doi: $10.1007 / \mathrm{s} 11104-007-9475-2$

Kong, Z., Li, L., Wu, J., Zhang, T., and Li, Y.-Y. (2019). Insights into the methanogenic degradation of $\mathrm{N}, \mathrm{N}$-dimethylformamide: the functional microorganisms and their ecological relationships. Bioresour. Technol. 271, 37-47. doi: 10.1016/j.biortech.2018.09.074

Krutz, L. J., Beyrouty, C. A., Gentry, T. J., Wolf, D. C., and Reynolds, C. M. (2005). Selective enrichment of a pyrene degrader population and enhanced pyrene degradation in Bermuda grass rhizosphere. Biol. Fertil. Soils 41, 359-364. doi: 10.1007/s00374-005-0844-9

Kuiper, I., Lagendijk, E. L., Bloemberg, G. V., and Lugtenberg, B. J. J. (2004). Rhizoremediation: a beneficial plant-microbe interaction. Mol. Plant Microbe Interact. 17, 6-15. doi: 10.1094/MPMI.2004.17.1.6

Kumar, V., AlMomin, S., Al-Aqeel, H., Al-Salameen, F., Nair, S., and Shajan, A. (2018). Metagenomic analysis of rhizosphere microflora of oilcontaminated soil planted with barley and alfalfa. PLoS ONE 13:e0202127. doi: 10.1371/journal.pone.0202127

Leistner, O.A. (2000). Seed Plants of Southern Africa: Families and Genera. Strelitzia 10. National Botanical Institute, Pretoria. Available online at: http:// 
biodiversityadvisor.sanbi.org/wp-content/themes/bst/keys/e-Key-20160604/ Index.html

Li, Y. H., Zhu, J. N., Liu, Q. F., Liu, Y., Liu, M., Liu, L., et al. (2013). Comparison of the diversity of root-associated bacteria in Phragmites australis and Typha angustifolia L. in artificial wetlands. World J. Microbiol. Biotechnol. 29, 1499-1508. doi: 10.1007/s11274-013-1316-2

Li, Y. H., Zhu, J. N., Zhai, Z. H., and Zhang, Q. (2010). Endophytic bacterial diversity in roots of Phragmites australis in constructed Beijing Cuihu Wetland (China). FEMS Microbiol. Lett. 309, 84-93. doi: $10.1111 / j .1574-6968.2010 .02015 . x$

Lorah, M. M., and Voytek, M. A. (2004). Degradation of 1,1,2,2-tetrachloro ethane and accumulation of vinyl chloride in wetland sediment microcosms and in situ porewater: biogeochemical controls and associations with microbial communities. J. Contam. Hydrol. 70, 117-145. doi: 10.1016/j.jconhyd.2003.08.010

Lu, L., Xing, D., and Ren, Z. J. (2015). Microbial community structure accompanied with electricity production in a constructed wetland plant microbial fuel cell. Bioresour. Technol. 195, 115-121. doi: 10.1016/j.biortech.2015.05.098

Luigimaria, B., Giovanni, B., Alessio, M., Roberto, D. P., and Lorenzo, B. (2014). Rhizosphere effect and salinity competing to shape microbial communities in Phragmites australis (Cav.) Trin. ex-Steud. FEMS Microbiol. Lett. 359, 193-200. doi: 10.1111/1574-6968.12565

Luisa, E., Lara, R., Francesco, F., and Stefania, P. (2004). Responses induced by high concentration of cadmium in Phragmites australis roots. Physiol. Plant. 121, 66-74. doi: 10.1111/j.0031-9317.2004.00295.x

Lv, Y., Yanyan, L.,i., Xiaohui, L., and Kun, X. (2020). The tolerance mechanism and accumulation characteristics of Phragmites australis to sulfamethoxazole and ofloxacin. Chemosphere 253:126695. doi: 10.1016/j.chemosphere.2020.126695

Lyu, Y. J., Huang, R., Zeng, J., and Wu, Q. L. (2020). Aquatic macrophytes and local factors drive bacterial community distribution and interactions in a riparian zone of lake Taihu. Water 12:432. doi: 10.3390/w12020432

Ma, X. M., and Burken, J. G. (2002). VOCs fate and partitioning in vegetation: use of tree cores in groundwater analysis. Environ. Sci. Technol. 36, 4663-4668. doi: $10.1021 /$ es $025795 j$

Ma, X. M., and Havelka, M. M. (2009). Phytotoxicity of chlorinated benzenes to Typha angustifolia and Phragmites communis. Environ. Toxicol. 24, 43-48. doi: $10.1002 /$ tox.20393

Majken, P., Claudia, B., and Hans, B. (2005). Tolerance and physiological responses of Phragmites australis to water deficit. Aquat. Bot. 81, 285-299. doi: 10.1016/j.aquabot.2005.01.002

Mang, K. C., and Ntushelo, K. (2021). Influence of acid mine water on the diversity and metabolite shift of microbial populations of the rhizosphere of common reed (Phragmites australis). Appl. Ecol. Environ. Res. 19, 395-411. doi: 10.15666/aeer/1901_395411

Marks, M., Lapin, B., and Randall, J. (1994). Phragmites australis: Threats, management, and monitoring. Nat. Areas J. 14, 285-294. doi: 10.294284/cabi.org/isc/abstract/19960706970

Mendes, R., Kruijt, M., de Bruijn, I., Dekkers, E., van der Voort, M., Schneider, J. H. M., et al. (2011). Deciphering the rhizosphere microbiome for disease-suppressive bacteria. Science 332, 1097-1100. doi: 10.1126/science.12 03980

Menka, K., and Tripathi, B. D. (2015). Efficiency of Phragmites australis and Typha latifolia for heavy metal removal from wastewater. Ecotoxicol. Environ. Saf. 112, 80-86. doi: 10.1016/j.ecoenv.2014.10.034

Meyerson, L. A., Saltonstall, K., Windham, L., Kiviat, E., and Findlay, S. (2000). A comparison of Phragmites australis in freshwater and brackish marsh environments in North America. Wetl. Ecol. Manag. 8, 89-103. doi: 10.1023/A:1008432200133

Miglioranza, K. S. B., de Moreno, J. E. A., and Moreno, V. J. (2004). Organochlorine pesticides sequestered in the aquatic macrophyte Schoenoplectus californicus (C.A. Meyer) Sojak from a shallow lake in Argentina. Water Resour. 38, 1765-1772. doi: 10.1016/j.watres.2004.01.017

Monferran, M. V., Wunderlin, D. A., Nimptsch, J., and Pflugmacher, S. (2007). Biotransformation and antioxidant response in Ceratophyllum demersum experimentally exposed to 1,2- and 1,4-dichlorobenzene. Chemosphere 68, 2073-2079. doi: 10.1016/j.chemosphere.2007. 02.016
Monterio, A., Moreira, I., and Sousa, E. (1999). Effect of prior common reed (Phragmites australis) cutting on herbicide efficacy. Hydrobiologia 415, 305-308. doi: 10.1007/978-94-017-0922-4_44

Nejla, H., Nadhira, B. A., Hassen, A., and Naceur, J. (2014). Evaluating the phytoremediation potential of Phragmites australis grown in pentachlorophenol and cadmium co-contaminated soils. Environ. Sci. Pollut. Res. Int. 21, 1304-1313. doi: 10.1007/s11356-013-1997-y

Obieze, C. C., Chikere, C. B., Selvarajan, R., Adeleke, R., Ntushelo, K., and Akaranta, O. (2020). Functional attributes and response of bacterial communities to nature-based fertilization during hydrocarbon remediation. Int. Biodeterior. Biodegrad. 154:105084. doi: 10.1016/j.ibiod.2020.105084

Packer, J. G., Meyerson, L. A., Skálov,á, H., Pyšek, P., and Kueffer, C. (2017). Biological flora of the British Isles: Phragmites australis. J. Ecol. 105, 1123-1162. doi: 10.1111/1365-2745.12797

Paola, C., Margherita, S., Rebeca, M., Giuseppe, B., Pier, P. R., and Giovanni, G. (2018). Mutual effect of Phragmites australis, Arundo donax and immobilization agents on arsenic and trace metals phytostabilization in polluted soils. Geoderma 314, 63-72. doi: 10.1016/j.geoderma.2017.10.040

Peltier, E. E., Webb, S. M., and Gaillard, J. (2003). Zinc and lead sequestration in an impacted wetland system. Adv. Environ. Res. 8, 103-112. doi: 10.1016/S1093-0191(02)00143-0

Peterson, L. (2010). A Field Guide to Edible Wild Plants of Eastern and Central North America. New York City, NY: Houghton Mifflin Company, 228.

Pflugmacher, S., Claudia, W., Kenneth, A. B., and Eberhard, K. (2001). Uptake, effects, and Metabolism of cyanobacterial toxins in the emergent reed plant Phragmites Australis (Cav.) Trin. Ex Steud. Environ. Toxicol. Chem. 20, 846-852. doi: 10.1002/etc.5620200421

Pietrangelo, L., Bucci, A., Maiuro, L., Bulgarelli, D., and Naclerio, G. (2018). Unraveling the Composition of the Root-Associated Bacterial Microbiota of Phragmites australis and Typha latifolia. Front. Microbiol. 9:1650. doi: $10.3389 /$ fmicb. 2018.01650

Pii, Y., Mimmo, T., Tomasi, N., Terzano, R., Cesco, S., and Crecchio, C. (2015). Microbial interactions in the rhizosphere: beneficial influences of plant growthpromoting rhizobacteria on nutrient acquisition process. A Rev. Biol. Fertil. Soils 51, 403-415. doi: 10.1007/s00374-015-0996-1

Pishgar, R., Dominic, J. A., Sheng, Z., and Tay, J. H. (2019). Denitrification performance and microbial versatility in response to different selection pressures. Bioresour. Technol. 281, 72-83. doi: 10.1016/j.biortech.2019.02.061

Raaijmakers, J. M., Paulitz, C. T., Steinberg, C., Alabouvette, C., and MoenneLoccoz, Y. (2009). The rhizosphere: a playground and battlefield for soilborne pathogens and beneficial microorganisms. Plant Soil 321, 341-361. doi: 10.1007/s11104-008-9568-6

Ravit, B., Ehrenfeld, J. G., and Haggblom, M. M. (2003). A comparison of sediment microbial communities associated with Phragmites australis and Spartina altemiflora in two brackish wetlands of New Jersey. Estuaries 26, 465-474. doi: $10.1007 / \mathrm{BF} 02823723$

Reimer, D. N. (1976). Long-term effects of glyphosate applications to Phragmites. J Aquat. Plant Manag. 14: 39-43. doi: 10.3943/japm/vol14/v14p39

Relyea, R. A. (2005). The lethal impact of roundup on aquatic and terrestrial amphibians. Ecol. Appl. 15, 1118-1124. doi: 10.1890/04-1291

Riva, V., Mapelli, F., Syranidou, E., Crotti, E., Choukrallah, R., Kalogerakis, N., et al. (2019). Root bacteria recruited by Phragmites australis in constructed wetlands have the potential to enhance azo-dye phytodepuration. Microorganisms 7:384. doi: 10.3390/microorganisms7100384

Rzymski, P., Niedzielski, P., Klimaszyk, P., and Poniedzialek, B. (2014). Bioaccumulation of selected metals in bivalves (Vnionidae) and Phragmites australis inhabiting a municipal water reservoir. Environ. Monit. Assess. 186, 3199-3212. doi: 10.1007/s10661-013-3610-8

Saleem, H., Arslan, M., Rehman, K., Tahseen, R., and Afzal, M. (2019). Phragmites australis-a helophytic grass-can establish successful partnership with phenoldegrading bacteria in a floating treatment wetland. Saudi J. Biol. Sci. 26, 1179-1186. doi: 10.1016/j.sjbs.2018.01.014

Saltonstall, K. (2002). Cryptic invasion by a non-native genotype of Phragmites australis into North America. Proceed. Nat. Acad. Sci. USA 99, 2445-2449. doi: $10.1073 /$ pnas. 032477999

Saltonstall, K., Castillo, H. E., and Blossey, B. (2014). Confirmed field hybridization of native and introduced Phragmites australis (Poaceae) in North America. Am. J. Bot. 101, 211-215. doi: 10.3732/ajb.1300298 
San, M. A., Julien, R., Jérôme, G., Armelle, M., Eric, C., Patrick, R., et al. (2014). Effects of organochlorines on microbial diversity and community structure in Phragmites australis rhizosphere. Appl. Microbiol. Biotechnol. 98, 4257-4266. doi: 10.1007/s00253-014-5545-6

San, M. A., Ravanel, P., and Raveton, M. (2013). A comparative study on the uptake and translocation of organochlorines by Phragmites australis. J. Hazard. Mater. 244, 60-69. doi: 10.1016/j.jhazmat.2012.11.025

Sanchez, A. A., Ferreira, A. C., Stopa, J. M., Bellato, F. C., Jesus, T. A.,d, Coelho, L. H. G., Domingues, M. R., et al. (2018). Organic matter, turbidity, and apparent color removal in planted (Typha sp. and Eleocharis sp.) and unplanted constructed wetlands. J. Environ. Eng. 144:06018007. doi: 10.1061/(ASCE)EE.1943-7870.0001443

Sauvêtre, A., Robert, M., Rudolf, H., Charlotte, P., and Peter, S. (2018). Metabolism of carbamazepine in plant roots and endophytic rhizobacteria isolated from Phragmites australis. J. Hazard. Mater. 342, 85-95. doi: 10.1016/j.jhazmat.2017.08.006

Savage, D. F., Afonso, B., Chen, A. H., and Silver,. P. A. (2010). Spatially ordered dynamics of the bacterial carbon fixation machinery. Science 327, 1258-1261. doi: $10.1126 /$ science. 1186090

Scott, L. (1982). A late quaternary pollen record from Transvaal bushveld, South Africa. Quat. Res. 17, 339-370. doi: 10.1016/0033-5894(82)90028-X

Shaw, L. J., Morris, P., and Hooker, J. E. (2006). Perception and modification of plant flavonoid signals by rhizosphere microorganisms. Environ. Microbiol. 8, 1867-1880. doi: 10.1111/j.1462-2920.2006.01141.x

Southichak, B., Nakano, K., Nomura, M., Chiba, N., and Nishimura, O. (2006). Phragmites australis: a novel biosorbent for the removal of heavy metals from aqueous solution. Water Res. 40, 2295-2302. doi: 10.1016/j.watres.2006.04.027

Srivastava, J., Kalra, S. J. S., and Naraian, R. (2014). Environmental perspectives of Phragmites australis (Cav.) Trin. Ex. Steudel. Appl. Water Sci. 4, 193-202. doi: 10.1007/s13201-013-0142-x

Srivastava, J. K., Chandra, H., Kalra, S. J. S., Mishra, P., Khan, H., and Yadav, P. (2017). Plant-microbe interaction in aquatic system and their role in the management of water quality: a review. Appl. Water Sci. 7, 1079-1090. doi: 10.1007/s13201-016-0415-2

Stottmeister, U., Wiessner, A., Kuschk, P., Kappelmeyer, U., Kästner, M., Bederski, O., et al. (2003). Effects of plants and microorganisms in constructed wetlands for wastewater treatment. Biotechnol. Adv. 22, 93-117. doi: 10.1016/j.biotechadv.2003.08.010

Sulaiman, M. S., and Alfadul, M. A. A. A. (2013). Effects of Cd, Cu, Pb, and $\mathrm{Zn}$ Combinations on Phragmites australis metabolism, metal accumulation and distribution. Arab. J Sci. Eng. 38, 11-19. doi: 10.1007/s13369-012-0393-0

Sun, H., Xu, S., Wu, S., Wang, R., Zhuang, G., Bai, Z., et al. (2019). Enhancement of facultative anaerobic denitrifying communities by oxygen release from roots of the macrophyte in constructed wetlands. J. Environ. Manage. 246, 157-163. doi: 10.1016/j.jenvman.2019.05.136

Thimmaraju, R., Yong, S. C., Delphis, F. L., David, R., Legates, K. H. L., and Harsh, P. B. (2009). Phragmites australis root secreted phytotoxin undergoes photodegradation to execute severe phytotoxicity. Plant Signal. Behav. 4, 506-513. doi: $10.4161 /$ psb.4.6.8698

Thompson, D. J., and Shay, J. M. (1985). The effects of fire on Phragmites australis in the Delta Marsh, Manitoba. Can. J. Bot. 63, 1864-1869. doi: 10.1139/b85-261

Tian, W., Zhao, Y., Sun, H., Bai, J., Wang, Y., and Wu, C. (2014). The effect of irrigation with oil-polluted water on microbial communities in estuarine reed rhizosphere soils. Ecol. Eng. 70, 275-281. doi: 10.1016/j.ecoleng.2014. 06.003

Toyama, T., Yusuke, S., Daisuke, I., Kazunari, S., Young-Cheol, C., Shintaro, K., et al. (2009). Biodegradation of bisphenol A and bisphenol $\mathrm{F}$ in the rhizosphere sediment of Phragmites australis. J. Biosci. Bioeng. 108, 147-150. doi: 10.1016/j.jbiosc.2009.03.011

Uroz, S., Calvaruso, C., Turpault, M. P., Pierrat, J. C., Mustin, C., and Frey-Klett, P. (2007). Effect of the mycorrhizosphere on the genotypic and metabolic diversity of the bacterial communities involved in mineral weathering in a forest soil. Appl. Environ. Microbiol. 73, 3019-3027. doi: 10.1128/AEM.00121-07

Van Oudtshoorn, F. (1999). "PHRAGMITES: questions and answers. United States Fish and Wildlife Service," inGuide to the grasses of southern Africa. Briza Publications: Pretoria.

Vladàr, P., Rusznyak, A., Marialigeti, K., and Borsodi, A. K. (2008). Diversity of sulfate-reducing bacteria inhabiting the rhizosphere of Phragmites australis in Lake Velencei (Hungary) revealed by a combined cultivation-based and molecular approach. Microb. Ecol. 56, 64-75. doi: 10.1007/s00248-007-9324-0

Wahman, R., Sauvêtre, A., Schröder, P., Moser, S., and Letzel, T. (2021). Untargeted Metabolomics Studies on Drug-Incubated Phragmites australis Profiles. Metabolites 11:2. doi: 10.3390/metabo11010002

Wang, F., Yan, Z., Liu, Y., Sun, C., and Ji, M. (2020). Nitrogen removal and abundances of associated functional genes in rhizosphere and non-rhizosphere of a vertical flow constructed wetland in response to salinity. Ecol. Eng. 158:106015. doi: 10.1016/j.ecoleng.2020.106015

Wang, L., Luo, X., Zhang, Y., Chao, J., Gao, Y., Zhang, J., et al. (2013). Community analysis of ammonia-oxidizing Betaproteobacteria at different seasons in microbial-earthworm ecofilters. Ecol. Eng. 51, 1-9. doi: 10.1016/j.ecoleng.2012.12.062

Wang, Q., Xie, H., Ngo, H. H., Guo, W., Zhang, J., Liu, C., et al. (2016). Microbial abundance and community in subsurface flow constructed wetland microcosms: role of plant presence. Environ. Sci. Pollut. Res. Int. 23, 4036-4045. doi: $10.1007 / \mathrm{s} 11356-015-4286-0$

Weis, J., and Weis, P. (2004). Metal uptake, transport and release by wetland plants: implications for phytoremediation and restoration. Environ. Int. 30, 685-700. doi: 10.1016/j.envint.2003.11.002

Wen, B., Li, X., Yang, F., Lu, X., Li, X., and Yang, F. (2017). Growth and physiology responses of Phragmites australis to combined drought-flooding condition in inland saline-alkaline marsh, Northeast China. Ecol. Eng. 108, 234-239. doi: 10.1016/j.ecoleng.2017.08.036

Wilson, F. P., Liu, X., Mattes, T. E., and Cupples, A. M. (2016). Nocardioides, Sediminibacterium, Aquabacterium, Variovorax, and Pseudomonas linked to carbon uptake during aerobic vinyl chloride biodegradation. Environ. Sci. Pollut. Res. Int. 23, 19062-19070. doi: 10.1007/s11356-016-7099-x

Windham, L., Weis, J. S., and Weis, P. (2001). Patterns and processes of mercury release from leaves of two dominant salt marsh macrophytes Phragmites australis and Spartina alterniflora. Estuar. 24, 787-795. doi: 10.2307/ 1353170

Windham, L., Weis, J. S., and Weis, P. (2003). Uptake and distribution of metals in two dominant salt marsh macrophytes, Spartina alterniflora (cordgrass) and Phragmites australis (common reed). Estuar. Coast. Shelf Sci. 56, 63-72. doi: 10.1016/S0272-7714(02)00121-X

Wu, J. T., Wang, L., Zhao, L., Huang, X. C., and Ma, F. (2020). Arbuscular mycorrhizal fungi effect growth and photosynthesis of Phragmites australis (Cav.) Trin ex. Steudel under copper stress. Plant Biol. 22, 62-69. doi: $10.1111 / \mathrm{plb} .13039$

Xing, W., Li, J., Li, P., Wang, C., Cao, Y., Li, D., et al. (2018). Effects of residual organics in municipal wastewater on hydrogenotrophic denitrifying microbial communities. J. Environ. Sci. 65, 262-270. doi: 10.1016/j.jes.2017. 03.001

Yang, C., Wang, M., Chen, H., and Li, J. (2011). Responses of butachlor degradation and microbial properties in a riparian soil to the cultivation of three different plants. J. Environ. Sci.23, 1437-1444. doi: 10.1016/S1001-0742(10) 60604-3

Yergeau, E., Tremblay, J., Joly, S., Labrecque, M., Maynard, C., Pitre, F. E., et al. (2018). Soil contamination alters the willow root and rhizosphere metatranscriptome and the root-rhizosphere interactome. ISME J. 12, 869-884. doi: 10.1038/s41396-017-0018-4

You, Y., Li, W., Chang, J., Gen, W., Fang, M., Yujiao, W., et al. (2021). Effects of arbuscular mycorrhizal fungi on the growth and toxic element uptake of Phragmites australis (Cav.) Trin. ex Steud under zinc/ cadmium stress. Ecotoxicol. Environ. Saf. 213:112023. doi: 10.1016/j.ecoenv.2021. 112023

Zhang, H., Ziv-El, M., Rittmann, B. E., and Krajmalnik-Brown, R. (2010). Effect of dechlorination and sulfate reduction on the microbial community structure in denitrifying membrane-biofilm reactors. Environ. Sci. Technol. 44, 5159-5164. doi: $10.1021 /$ es 100695 n

Zhang, J. Y., Zhao, W., Pan, J., Qiu, L. M., and Zhu, Y. M. (2005). Tissue-dependent distribution and accumulation of chlorobenzenes by vegetables in urban area. Environ. Int. 31, 855-860. doi: 10.1016/j.envint.2005.05.034

Zhang, W., Wu, X., Liu, G., Chen, T., Zhang, G., Dong, Z., et al. (2013). Pyrosequencing reveals bacterial diversity in the rhizosphere of three Phragmites australis ecotypes. Geomicrobiol. J. 30, 593-599. doi: 10.1080/01490451.2012.740145 
Zhang, X., He, R., Su, R., Zeng, J., Zhou, Q., Huang, R., et al. (2021). Composition and co-occurrence network of the rhizosphere bacterial community of two emergent macrophytes and implications for phytoremediation. Marine Freshwater Res. 9:1689. doi: 10.1071/MF20082

Zhang, X., Zhao, S., Gao, J., Lei, Y., Yuan, Y., Jiang, Y., et al. (2019). Microbial action and mechanisms for $\mathrm{Cr}(\mathrm{VI})$ removal performance by layered double hydroxide modified zeolite and quartz sand in constructed wetlands. J. Environ. Manage. 246, 636-646. doi: 10.1016/j.jenvman.2019. 06.017

Zhao, Y., Yang, Z., Xia, X., and Wang, F. (2012). A shallow lake remediation regime with Phragmites australis: incorporating nutrient removal and water evapotranspiration. Water Res. 46, 5635-5644. doi: 10.1016/j.watres.2012.07.053

Zou, J., Liu, X., He, C., Zhang, X., Zhong, C., Wang, C., et al. (2013), Effect of Scripus triqueter of its rhizosphere and root exudates on microbial community structure of simulated diesel-spiked wetland. Int. Biodeterior. Biodegrad. 82, 110-116. doi: 10.1016/j.ibiod.2013. 03.006
Conflict of Interest: The authors declare that the research was conducted in the absence of any commercial or financial relationships that could be construed as a potential conflict of interest.

Publisher's Note: All claims expressed in this article are solely those of the authors and do not necessarily represent those of their affiliated organizations, or those of the publisher, the editors and the reviewers. Any product that may be evaluated in this article, or claim that may be made by its manufacturer, is not guaranteed or endorsed by the publisher.

Copyright (c) 2021 Kalu, Rauwane and Ntushelo. This is an open-access article distributed under the terms of the Creative Commons Attribution License (CC BY).

The use, distribution or reproduction in other forums is permitted, provided the original author(s) and the copyright owner(s) are credited and that the original publication in this journal is cited, in accordance with accepted academic practice. No use, distribution or reproduction is permitted which does not comply with these terms. 